\title{
THE EFFECT OF THE WORK-FAMILY CONFLICT AND EMPLOYEE'S JOB SATISFACTION TOWARDS THE ORGANIZATION COMMITMENT
}

\author{
Harrie Lutfie \\ Arif Partono Prasetio \\ Dini Turipanam Alamanda \\ TELKOM University, School of Economic and Business \\ e-mail: partono67@gmail.com; partono@telkomuniversity.ac.id
}

\begin{abstract}
Companies in Indonesia are facing more challenging business and the high intensity of competition between the players.To cope with the competition, company need to prepare their resources well. The high demand and fierce competition in all industry make the company difficult to find a good people. The scarcity of human resources required the company to maintain the people who already work for them.Employers want their employees to have a strong commitment towards the job and organization. This research will identify the job satisfaction and the work-family conflict experienced by the employees and analyze whether they have an effect towards the organization commitment. We distribute the questionnaire in an online method for two weeks and we have 79 respondents from several industries. The descriptive analysis and multiple regressions conducted to analyze the findings. The research showed the level of work-family conflict experience by employeesare average, the job satisfaction level is quite high, and the organization commitment is at low level. We also found that the relation between work-family conflict and job satisfaction with employee commitment is relatively weak $(R=0,412)$. Also the contribution from both independent variables is only 0,169 (16,9\%). Simultaneously, the organization commitment affected by the work family conflict and job satisfaction. Partially, only job satisfaction which significantly affect the organization commitment.
\end{abstract}

Keywords: work-family conflict, job satisfaction, employee commitment, multiple regressions

\begin{abstract}
Abstrak
Perusahaan-perusahaan di Indonesia sedang menghadapi tantangan bisnis yang lebih dan tingginya intensitas kompetitif di antara pelaku bisnis. Untuk mengatasi kompetisi tersebut, perusahaan dipandang perlu untuk menyiapkan sumberdaya yang dimiliki dengan baik. Tingginya permintaan dan sengitnya kompetisi di seluruh industri telah membuat perusahaan kesulitan untuk menemukan kandidat karyawan yang tepat/baik. Kelangkaan sumberdaya ini mengharuskan perusahaan untuk menjaga dan memelihara karyawan yang ada dan telah berkontribusi untuk perusahaan. Di sisi lain, perusahaan menginginkan karyawan mereka berkomitmen kuat terhadap pekerjaan dan organisasi/perusahaan. Penelitian ini mengidentifikasi kepuasan kerja dan konflik kerja-keluarga yang dialami karyawan dan menganalisa apakah kedua variabel tersebut berpengaruh pada komitmen organisasi. Kami mendistribusikan kuesioner dengan metode daring selama dua minggu dan memperoleh 79 responden dari beberapa industri. Analisis deskriptif dan regresi berganda digunakan untuk menganalisa temuan. Hasil menunjukkan bahwa level konflik kerja-keluarga yang dialami karyawan adalah rata-rata, level kepuasan kerjanya tinggi, dan komitmen organisasi pada level rendah. Kami juga menemukan hubungan antara konflik kerjakeluarga dan kepuasan kerja dengan komitmen karyawan relatif lemah $(\mathrm{R}=0,412)$. Demikian pula, kontribusi kedua variabel independen hanya sebesar 0,169 (16,9\%). Secara simultan, komitmen organisasi dipengaruhi oleh konflik kerja-keluarga dan kepuasan kerja. Namun, secara parsial, hanya kepuasan kerja yang berpengaruh secara signifikan pada komitmen organisasi.
\end{abstract}

Kata kunci: konflik kerja-keluarga, kepuasan kerja, komitmen karyawan, regresi berganda 


\section{INTRODUCTION}

Companies faced significant threat regarding their sustainability. This is because of the increasing competition and the scarcity of the vital resources. No wonder that this condition cause them to push their employees to give their best. In fact the organization commitment can lead to the achievement of organization's goals (Fu \&Deshpande, 2013). On the other hand, employee willing to shares their part of the bargain and nothing more. This can clearly understand because employees are also human being who usually other needs, their individual and family need(Boyar et al, 2008:216; Bruck et al, 2002). Their reasons to work are both to fulfill their life and live their life. They need to achieve both in a balance way. Employee will perceive the balance when their needs are met. So, if the company wants to develop their commitment they should take care of them first. When employee perceives the organization takes care of them, they often reply with the high commitment. Creating job satisfaction and providing the policy that can reduce potential work-family conflict can be chosen as the tools to make them think that the organization considered them as an important asset (Akintayo, 2010; Bruck et al, 2002). The goal of this research is to find whether the work-family conflict and job satisfaction affect the employee's level of organization commitment.

\section{LITERATURE REVIEW}

In order to explain those connections, we provide the literature background for all of the variables.A numerous literature has been written to analyze the work-familyconflict and their consequences (Greenhaus\&Beutell, 1985; Wharton dan Blair-Loy, 2006, Rantanen et al, 2011; Boyar et al, 2008; Grant-Vallone\& Donaldson, 2001; Karatepe\&Baddar, 2006). Work-family conflict defined as the demands of the work interfere with fulfilling family responsibilities (Wharton \& Blair-Roy, 2006) and the well-known definition of WFC and used widely is from Greenhaus\&Beutell, "a form of inter-role conflict in which the role pressures from the work and family domains are mutually incompatible in some respect. That is, participation in the work (family) role is made more difficult by virtue of participation in the family (work) role". When discussing the WFC we should also include the analysis of the spillover theory (Hill, Ferris, \& Martinson, 2003), role theory (Rantanen, 2011), and role conflict theory (Fredriksen-Goldsen\&Scharlach, 2001). This is because the WFC composed of those ingredients. Role in the family and role at work are spillover in each other which inevitably cause the conflict to occur. To provide the analysis of the work-family conflict (WFC) we use the article from Greenhause\&Beutell (1985) which divide the WFC into two domain, work interfere family and family interfere work. Inside these two domains, Greenhaus\&Beutell(1985, 77-82) also use and explain three dimensions time-based, strainbased, and the behavior-based conflict. As for the WFC measurement, we use the questionnaire from Greenhaus\&Beutell to accommodate the language barrier for the respondents. Of course several adjustments had been made to adjust to the Indonesia condition.

Robbins \& Judge (2013) define the job satisfaction defined as a positive feeling about a job resulting from an evaluation of its characteristics. While Gibson et al (2012) view the satisfaction as an individual's expression of personal well-being associated with doing the job assigned. Both definitions explain that job satisfaction is a feeling from the employees towards their current work/job. It has been long known that a satisfied employee was a highperforming employee. Happy workers are more likely to be productive workers. Satisfied employees would seem more likely to talk positively about the organization, help others, go beyond the normal expectations in their job, reciprocates their positive experiences (Robbins \& Judge, 2013). Wagner \& Hollenbeck (2009) argue that the satisfaction \& performance link is especially strong in the service industry where employees have direct, face-toface contact with customers. And while satisfaction can affect the performance, the dissatisfaction can contributes to declining organizational commitment. To measure the level of job satisfaction, this research use the method which sum up the five facets of job, such as; the nature of the work, supervision, present pay, promotion opportunities, and the relationships with co-workers. We develop the 20 items questionnaire based on the previous Job Descriptive Index questionnaire. 
Analyzing the organization commitment cannot be separated from the work of Meyer \& Allen (1990, 1991, \& 1996). The organization commitment define as the loyalty of an individual to the organization (Schermerhorn et al, 2012), or a sense of identification, loyalty, and involvement expressed by an employee toward the organization or unit of the organization (Gibson et al, 2012). It means the commitment is a feeling of loyalty from the employee towards their organization. Employee with very high organizational commitment will have strong identification toward their organization and take pride as the members. Research indicates that the absence of commitment can reduce organizational effectiveness. This showed the importance of having highly committed employees. Meyer\&Allen (1991) argued that the concept of the commitment has multidimensional construct, in which consist of three components; affective, continuant, and normative. The first component related with the employee's tendency to remain involved in a series of activity. Affectivecommitment also related with the emotional tied of individual with the company. The second component, continuant commitment, related with the calculation about the loss and gain which will employee experienced when they leaves theorganization. When they felt that the loss is greater than the benefit they will choose to stay. The last component, normative commitmentrelated with the sense of obligation of employeesto continuously work for the organization. We adapted the 24 items from the original Meyer \& Allen questionnaire (1990) to measure the organization commitment.
We construct the research model as in Figure 1. To support the model, we review several journals. Wang et al (2010), Buonocore\& Russo (2012), and Ergeneli et al (2010) discuss the relation between WFC and job satisfaction. They found that WFC has negative relation with job satisfaction level. Furthermore, Azeem (2010), Irshad \& Naz (2011), Gunlu et al (2010), Sejjaaka \& Kaawaase (2014) found the positive relation with the organization commitment. Meanwhile, regarding the WFC and organization commitment, Rehman \& Waheed (2012), Zulfiqar et al (2014), and Mihelič \& Tekavčič (2014) found that WFC will affect the individual commitment towards the organization. The next discussion on previous research directed on the overall relation between WFC, job satisfaction and organization commitment. The works of Haar (2008), Sethi (2012), Azeem (2010), and Gunlu et al (2010) show the diversity of each result. From this point of view, we hope this research can contribute for the further study of WFC, job satisfaction, and organization commitment from the various industries and the measurement tools.

The hypotheses for the study are:

1. $\mathrm{H}_{0}$ a: there is no significance relationship between work-family conflict and organization cm mitment.

2. $\mathrm{H}_{1}$ a: there is significance relationship between work-family conflict and organization commitment.

3. $\mathrm{H}_{0} \mathrm{~b}$ : there is no significance relationship between job satisfaction and organization commitment.

4. $\mathrm{H}_{1} \mathrm{~b}$ : there is significance relationship between job satisfaction and organization commitment.

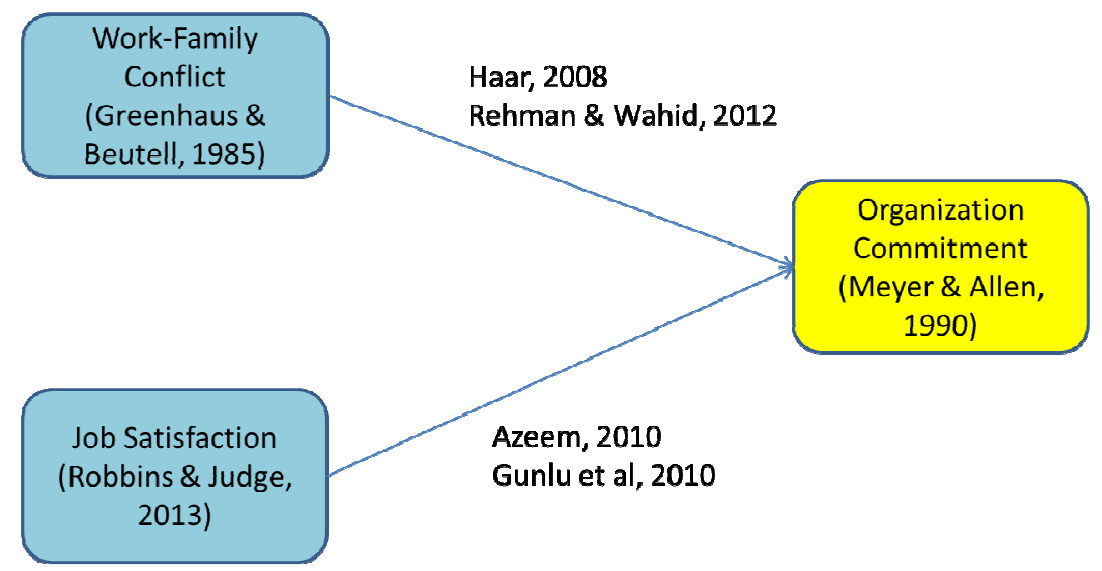

Figure I. Research Model 
5. $\mathrm{H}_{0} \mathrm{c}$ : there is no significance relationship between work-family conflict and job satisfaction on organization commitment.

6. $\mathrm{H}_{1} \mathrm{c}$ : there is significance relationship between work-family conflict and job satisfaction on organization commitment.

\section{Methodology}

This research used causal method to explain the phenomenon and using multiple regressions to analyze the relation between variables. There are two independent variables and one dependent variable in the study which are workfamily conflict, job satisfaction, and organizational commitment. Using 79 samples as respondents, the data were collected using online questionnaire and consist of employees from several industries. Further, convenient sampling method was used consideringthe availability and the willingness to participate of the respondent. We used five point scale (Likert) where (5) means strongly agree and (1) means strongly disagree for all items in the instrument. We apply the 18 statements derived from Greenhaus\&Beutell (1985) to measure the degree of work-family conflict (item one deleted because it is not valid). The second variable, Job Satisfactionis measured using the selfadministered questionnaire created based on the Job Descriptive Index (Robbins \& Judge, 2013). The questionnaire consists of 20 items with 5-point Likert scale and all met the validity criteria. The commitment variable measuredby the Meyer \& Allen questionnaire (1991) consist of 24 items. Which it turn out only 18 of them valid.

\section{Result and Discussion}

Table 1 showed that the work-family conflict faced by the employee can be categorized as high. This means that the employee has problems managing their work and family life. From the numbers and percentage below, it turns out that the family interfere work has higher percentage. We assume the employee face more pressure from their family life and it may affect their work performance. To overcome the condition, company can provide support for their employee if they need help managing their family matters.

We are now looking at Figure 1. It showed how close the work-family conflict level score with the average level. We suggest that both company and the employees willing to try to identify what is the most probable cause for this situation. This finding can also be viewed that the employee still consider family matters important so they will prioritize the family need, even if they have to set aside their work. Is this the ideal condition? The question should answer with many considerations.

Regarding the job satisfaction level, Table 2 indicates that employee's level on satisfaction is high on three of five indicators. Employees perceived high job satisfaction with the opportunity for the promotion, the work they do, and their co-worker.

Table 1: Work-Family Conflict Level

\begin{tabular}{lrrrrrrr}
\hline & \multicolumn{1}{c}{ VL } & \multicolumn{1}{c}{ L } & \multicolumn{1}{c}{ AV } & H & VH & & \\
\hline & 1 & 2 & 3 & 4 & 5 & 79 & 395 \\
WIF & 2,625 & 18,5 & 10,875 & 41 & 6 & 266,25 & $67,45 \%$ \\
FIW & 0,77778 & 13,8889 & 14,6667 & 40,8889 & 8,77778 & 280 & $70,9 \%$ \\
& & & & & & 273,125 & $69,1 \%$ \\
\hline
\end{tabular}

VL= Very Low; L= Low; AV= Average; H= High; VH= Very High

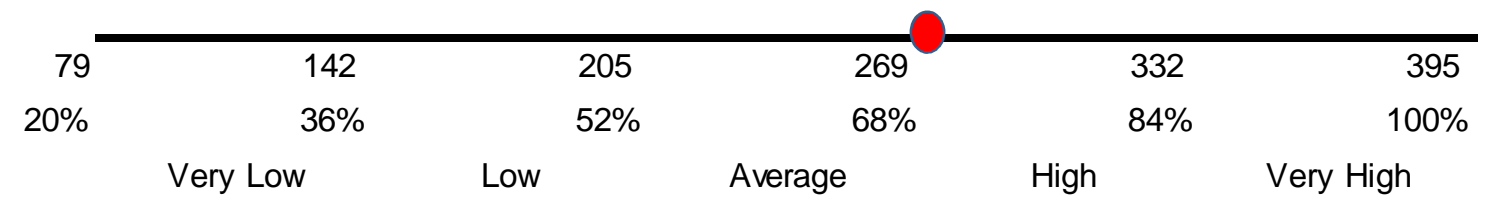

Figure 1 Continuum Line for Work-Family Conflict 
Table 2: Employee's Satisfaction Level

\begin{tabular}{|l|c|c|c|c|c|c|c|c|}
\hline & & VNS & NS & AV & S & VS & & \\
\hline & & 1 & 2 & 3 & 4 & 5 & 79 & 395 \\
\hline Income & 3,25 & 23,5 & 17,75 & 31,25 & 3,25 & 244,75 & $62,0 \%$ \\
\hline Promotion & 1 & 5 & 12,25 & 47,5 & 13,25 & 304 & $77,0 \%$ \\
\hline Work itself & 0,25 & 6 & 12,25 & 51 & 9,5 & 300,5 & $76,1 \%$ \\
\hline Superisor & 0,75 & 15,5 & 26,5 & 30 & 6,25 & 262,5 & $66,5 \%$ \\
\hline Co Worker & 1,25 & 5 & 17,75 & 49,75 & 5,25 & 289,75 & $73,4 \%$ \\
\hline & & & & & & 280,3 & $71,0 \%$ \\
\hline \multicolumn{2}{|l|}{ VNS= Not Very Satsfied; NS=Not Satisfied; AV=Average; S=Satisfied; VS=Very Satisfied } \\
\hline
\end{tabular}

Meanwhile their satisfaction is average on the other two factors, income and the supervisor. The company needs to pay attention about these indicators. Nevertheless, money is still considered the most important thing for workers. The satisfaction towards the supervisor is somewhat unique. Is it the fault of the supervisor when employee felt not satisfied? Of course is not that simple. Supervisor's job is not to make the subordinate happy. They have to pursue the company goals with the help of the employees. In doing so, sometime supervisor put some pressure which can cause dissatisfaction. The key in this matter is the timing of the supervisor to identify when they should let the employee do as they want as long as the goals achieved and when they should manage with containment. The Figure 2 showed the exact position of the satisfaction and in fact it is not high enough. The closeness with the aver- age level indicates that the employee satisfaction is fragile. The movement towards the average level can happen if the company fails to produce the desired condition.

The last variable, organization commitment has the lowest rating compare with two previous variables. As we can see on Table 3 the commitment level is only average. This is not too good for the company. The company should be careful when managing their employees. From the result below it showed that the lowest portion is resulting from the continuance commitment.

Company need to create valuable offer so that the employee felt that if they move to other company, they will not get better deals. Or at least they will have to think several times before decide to move out. In this way the employee will feel safe and willing to stay longer in the organization.

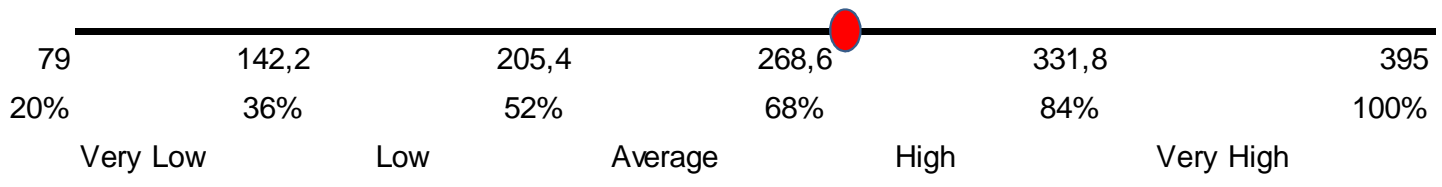

Figure 2 Continuum Live for Job Satisfaction

Table 3: Organization Commitment Level

\begin{tabular}{|l|c|c|c|c|c|c|r|r|}
\hline & VW & W & AV & S & VS & & \\
\hline & & 1 & 2 & 3 & 4 & 5 & 79 & 395 \\
\hline Affective Commitment & 0,5 & 7,833333 & 26 & 39,66667 & 5 & 277,8333 & $70,3 \%$ \\
\hline Continuance Commitment & 4,5 & 24,125 & 27,75 & 20,5 & 2,125 & 228,625 & $57,9 \%$ \\
\hline Normative Commitment & 1 & 10 & 19,5 & 40,25 & 8,25 & 281,75 & $71,3 \%$ \\
\hline & & & & & & 262,7361 & $66,5 \%$ \\
\hline
\end{tabular}

Figure 3 Continuum Line for Organization Commitment 
We have our descriptive analysis regarding the level of work-family conflict, job satisfaction, and the organization commitment. We now will look at the relation of those variables. The version 22 of SPSS used to get the result. We presented the result starting from the classical assumption test. The data met the normality test because the Asymp. Sig. (2tailed) show the figure of 0,200 which more than 0,05 .

The significance for the heteroscedasticityboth are more than $0,05(0,937$ for the work-family conflict and 0,193 for the job satisfaction. The multi collinearitytest also indicates the work-family conflict (WFC) and job satisfaction are passed. The figure for WFC is 0,996 and 1,004. Meanwhile for the satisfaction are the same. This mean the model can be proceed to multiple regressions.

This study found that Sig. (2-tailed) of the WFC on commitment is 0,129 which is bigger than 0,05 . It means the hypothesis $\mathrm{H0a}$ is accepted, that is to say there is no significance relationship between work-family conflict and organization commitment. Meanwhile, the Sig. (2-tailed) of the job satisfaction on commitment is 0,001 which is smaller than 0,05 . It can be said that HOb rejected and the H1b accepted. There is significance relationship between job satisfaction and organization commitment. The result mean that partially, only job satisfaction affecting organization commitment. We can look at the Sig. level which is 0,001 for job satisfaction and 0,064 for workfamily conflict.

Table 4: Coefficients

Coefficients $^{a}$

\begin{tabular}{|c|c|c|c|c|c|c|c|}
\hline \multirow[b]{2}{*}{ Model } & \multicolumn{2}{|c|}{$\begin{array}{l}\text { Unstandardized } \\
\text { Coefficients }\end{array}$} & \multirow{2}{*}{ 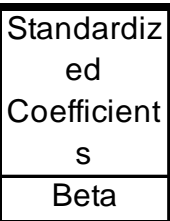 } & \multirow[b]{2}{*}{$\mathrm{t}$} & \multirow[b]{2}{*}{ Sig. } & \multicolumn{2}{|c|}{ Collinearity Statistics } \\
\hline & $\mathrm{B}$ & Std. Error & & & & Tolerance & VIF \\
\hline (Constant) & 50,098 & 6,205 & & 8,074 & , 000 & & \\
\hline WFC &,- 139 &, 074 &,- 197 & $-1,877$ & ,064 & 996 & 1,004 \\
\hline $\begin{array}{l}\text { SATISFACTIO } \\
\mathrm{N}\end{array}$ & 234 & ,066 & ,375 & 3,576 & 001 & 996 & 1,004 \\
\hline
\end{tabular}

a. Dependent Variable: COMMITMENT

Table 5: Pearson Correlation

\begin{tabular}{|c|c|c|c|c|}
\hline & & WFC & SATISFACTION & COMMITMENT \\
\hline \multirow[t]{3}{*}{ WFC } & Pearson Correlation & 1 &, 065 &,- 172 \\
\hline & Sig. (2-tailed) & & ,567 & 129 \\
\hline & $\mathrm{N}$ & 79 & 79 & 79 \\
\hline \multirow[t]{3}{*}{ SATISFACTION } & Pearson Correlation & ,065 & 1 & ,362* \\
\hline & Sig. (2-tailed) & ,567 & & ,001 \\
\hline & $\mathrm{N}$ & 79 & 79 & 79 \\
\hline \multirow[t]{3}{*}{ COMMITMENT } & Pearson Correlation &,- 172 & ,362** & 1 \\
\hline & Sig. (2-tailed) & 129 & ,001 & \\
\hline & $\mathrm{N}$ & 79 & 79 & 79 \\
\hline
\end{tabular}


Table 6: Annova

\begin{tabular}{|c|c|c|c|c|c|c|}
\hline \multicolumn{2}{|c|}{ Model } & $\begin{array}{c}\text { Sum of } \\
\text { Squares }\end{array}$ & df & $\begin{array}{l}\text { Mean } \\
\text { Square } \\
\end{array}$ & $\mathrm{F}$ & Sig. \\
\hline \multirow[t]{3}{*}{1} & Regression & 483,410 & 2 & 241,705 & 7,750 & 0,001 \\
\hline & Residual & 2370,311 & 76 & 31,188 & & \\
\hline & Total & 2853,722 & 78 & & & \\
\hline \multicolumn{7}{|c|}{ a. Dependent Variable: COMMITMENT } \\
\hline \multicolumn{7}{|c|}{ b. Predictors: (Constant), SATISFACTION, WFC } \\
\hline
\end{tabular}

Table 7: Model Summary

\begin{tabular}{|l|r|r|r|r|}
\hline Model & $\mathrm{R}$ & $\mathrm{R}$ Square & $\begin{array}{c}\text { Adjusted } \\
\text { R Square }\end{array}$ & $\begin{array}{c}\text { Std. Error } \\
\text { of the } \\
\text { Es timate }\end{array}$ \\
\hline 1 &, $412^{\mathrm{a}}$ &, 169 &, 148 & 5,58465 \\
\hline
\end{tabular}

b. Dependent Variable: COMMITMENT

When conducted simultaneous analysis on WFC and job satisfaction we found that they produce sig. 0,001 which can be seen at Table 6 . This number is below the significance level of 0,05 . That means this regression model can be used to predict the organization commitment. This finding answered the question about the relation of WFC and job satisfaction on organization commitment. The sig. Level at 0,001 (below 0,005$)$ and the F-calculate $(7,750)$ is bigger than F-table $(3,12)$ so we can say the $\mathrm{HOc}$ is rejected and H1c accepted. Simultaneously, there is significance relationship between work-family conflict and job satisfaction on organization commitment.

We arrive at the last part of the discussion. The next analysis will be based on the Table 7 of model summary. If we look at the result on Table 6 , we can identify that the value of $R$ is 0,412 . $R$ value below 0,5 mean the correlation between variables are weak (in scale of 0 to 1). WFC and job satisfaction have weak correlation with organization commitment.

The $\mathrm{R}$ square value show a low level of percentage, $0,169(16,9 \%)$. This mean the contribution of WFC and job satisfaction towards commitment is only $16,9 \%$. Or only $16,9 \%$ of the commitment can be explained by the WFC and job satisfaction. The other $83,1 \%$ explained by other factors which are not discussed in the model. As for the respective variables, we referred to the Table 4 which shows that the work-family conflict has beta coefficient 0,197 , while job satisfaction has 0,375 . Workfamily conflict usually has negative relation, it means that if the conflict rise then the organiza- tion commitment will reduce or become lower. In this case, the work-family conflict has no relation on the commitment. Meanwhile, the job satisfaction has effect on the commitment. It is widely known that if someone happy and satisfies he/she will felt more attached or commit. So we support the general view that satisfaction leads to the high commitment.

\section{CONCLUSION}

We finally come to the conclusion of this research Differ from other scientific paper, this research find a weak relation between WFC and job satisfaction on organization commitment. When analyzed these variables separately, the WFC does not have significance relation on commitment. Our opinion about this matter is that employees realize they have to make sacrifice when they decide to work. So, they usually prepare for the situation which led to the conflicting situation between job and family matters. Regarding the job satisfaction which found has effect on commitment, the company need to find ways to enhance the satisfaction. They can start with the better career opportunity and more challenging work. In this way, employee felt rewarded for their effort. They want to move higher in the career ladder. Inform them while there are vacancies and also explain how to achieve them. Provide the clear career path and fair system for employee to have the chance. Meanwhile, there are other factors which also affecting the commitment. If the company wants to increase the employee's 
commitment, they have to look for other factors which have stronger impact.

It should be noted that the research is only used 79 respondents, which still relatively small. In the future we will use more respondent whose represent employees from various industries. We also stated that there are other factors which affect the organization commitment. We propose that the role of the leader, the company image, the challenging work, and the opportunity to grow are several factors which can be consider. Company should also conduct the routine discussion to gather the information from employee about what they expect from the job and organization.

\section{REFERENCES}

Akintayo, D. I. (2010). Work-family role conflict and organizational commitment among industrial workers in Nigeria. Journal of Psychology and Counseling, Vol. 2, No. 1, pp.1-8.

Azeem, Syed Mohammad. (2010). Job Satisfaction and Organizational Commitment among Employees in the Sultanate of Oman. Psychology, 2010, 1, 295-299.

doi:10.4236/psych.2010.14038.

Buonocore, F. \& M. Russo. (2012) 'Reducing the effects of work-family conflict on job satisfaction: the kind of commitment matters'. Human Resource Management Journaldoi: 10.1111/j.17488583.2011.00187.x

Bruck, C. S., TD. Allen, \& PE. Spector. (2002). The Relation between Work-Family Conflict and Job Satisfaction: A FinerGrained Analysis. Journal of Vocational Behavior, 60, pp. 336-353. doi:10.1006/jvbe.2001.1836.

Boyar, S.L., C.P. Maertz Jr., D.C. Mosley Jr., \& J.C. Carr. (2008). The Impact of Work/Family Demand on WorkFamily Conflict.Journal of Managerial Psychology, 23 (3) : 215 - 235.

Ergeneli, A., A. Ilsev, \& PH. Karapınar. (2010). Work-family Conflict and Job Satisfaction Relationship: The Roles of Gender and Interpretive Habits. Gend- er, Work and Organization. Vol. 17 No. 6, pp. 679-695.

Frederik-Goldsen, K.I., \& AE. Scharlach. (2001). Families and Work; New Directions in the Twenty First Century. New York. Oxford Univeristy Press.

Fu, W., \& SP. Deshpande. (2013).The Impact of Caring Climate, Job Satisfaction, and Organizational Commitment on Job Performance of Employees in a China's Insurance Company.Journal Business Ethics. Springer Science + Business Media Dordrecht (online).

Greenhaus, J.H., \& NJ. Beutell. (1985). Sources of Conflict Between Work and Family Roles. The Academy of Management Review.Januari, 76-88.

Gibson, J.L., JM. Ivancevich, JH. Donnelly Jr, \& R. Konopaske. (2012). Organizations: Behavior, Structure, Processes, $14^{\text {th }}$ edition. New York: McGraw-Hill

Grant-vallone, E.J., \& SI. Donaldson. (2001). Consequences of work-family conflict on employee well-being over time. Work and Stress, 15 (3), 214-226.

Gunlu, E., M. Aksarayli, \& NS. Percin. (2010).Job satisfaction and organizational commitment of hotel managers in Turkey.International Journal of Contemporary Hospitality Management. Vol. 22 No. 5, pp. 693-717.

Haar, J. (2008). Work-Family Conflict and Job Outcomes: The Moderating Effectsof Flexitime Use in a New Zealand Organization. New Zealand Journal of Employment Relations, 33(1): 38-54.

Hill, E.J., M. Ferris, \& V. Martinson. (2003). Does it matter where you work? A comparison of how three work venues (traditional office, virtual office, and home office) influence aspects of work and personal/family life. Journal of Vocational Behavior, 63, 220-241.

Irshad, E., \& S. Naz. (2011). Job Satisfaction, Organizational Commitment and Personality Traits: A relationship Study. Journal of Humanities and Social Science Vol. XIX, No. 2, pp. 37 -60. 
Karatepe, O.M., \& L. Baddar. (2006).An empirical study of the selected consequences of frontline employees' workfamily conflict and family-work conflict.Tourism Management. 27, pp. 1017-1028.

Meyer, J.P., \& NJ. Allen. (1990).The measurement and antecedents of affective, continuance and normative commitment to the organization.Journal of Occupational Psychology, Vol. 63, pp. 1-18.

Meyer, J.P., \& NJ. Allen. (1991). A Three Component Conceptualization of Organizational Commitment. Human Resource Management Review. Vol. 1, No. 1, pp. 61-89.

Meyer, J.P. \& NJ. Allen. (1996). Affective, Continuance, and Normative Commitment to the Organization: An Examination of Construct Validity. Journal of Vocational Behavior.Vol. 49, pp. 252276.

Mihelič, K.K., \& M. Tekavčič. (2014). WorkFamily Conflict: A Review Of Antecedents And Outcomes. International Journal of Management \& Information Systems. Vol. 18, No. 1, pp 15-26.

Rantanen, J., U. Kinnunen, S. Mauno, \& K. Tillemann. (2011). Introducing Theoretical Approaches to Work-Life Balance and Testing, a New Typology Among Professionals, in Creating Balance? International Perspectives on the work-life Integration of Professionals. Berlin. Springer.

Rehman, R.R., \& A. Waheed. (2012). WorkFamily Conflict and Organizational Commitment: Study of Faculty Members in Pakistani Universities. Pakistan Journal of Social and Clinical Psychology. Vol. 10, No. 1, pp. 23-26.
Robbins, S.P., \& TA. Judge. (2013). Organizational Behavior, $15^{\text {th }}$ edition. New Jersey: Pearson Education Inc.

Sejjaaka, S.K., \& TK. Kaawaase. (2014). Professionalism, rewards, job satisfaction and organizational commitment amongst accounting professionals in Uganda. Journal of Accounting in Emerging Economies. Vol. 4 No. 2, pp. 134-157.

Sethi, G. (2012). Job Satisfaction in Relation to Organizational Citizenship Behavior, Organization Commitment, and WorkFamily Balance. International Journal of Technical Research. Vol 1, Issue 2, Nov-Dec, Page 5.

Schermerhorn, Jr. J.R., RN. Osborn, M. UhlBien, \& JG. Hunt. (2012). Organizational Behavior, $12^{\text {th }}$ edition. New Jersey: John Wiley \& Sons.

Wagner III, J.A., \& JR. Hollenbeck. (2010). Organization Behavior, Securing Competitive Advantage (revised edition). New York \& Oxon: Routledge.

Wharton, A.S., \& M. Blair-Loy. (2006). Long Work Hour and Family Life; A CrossNational Study of Employee Concerns, Journal of Family Issues 27 (3). 415436.

Wang, P., JJ. Lawler, and K. Shi. (2010). Work-Family Conflict, Self-Efficacy, Job Satisfaction, and Gender: Evidences From Asia. Journal of Leadership \& Organizational Studies. Vol. 17, No. 3, pp. 298-308.

Zulfiqar, A., GM. Kundi, QA. Qureshi, N. Khan, R. Akhtar, \& MYS. Khan. (2014). Public Policy and Administration Research.ISSN 2224-5731(Paper) ISSN 2225-0972(Online). Vol.3, No.4, pp. 58-63. 